\title{
Intrafamilial Transmission of Hepatitis C Virus among Household Members of Hepatitis C Virus Patients
}

\author{
Mohammad F. Tolba', Adel A. Hassan', Mahmoud M. Sheded ${ }^{2}$, and \\ Fatma R. Moussa ${ }^{2 *}$ \\ ${ }^{1}$ Dept of Endemic and Infectious Diseases, Faculty of Medicine, Suez Canal University, Egypt and ${ }^{2}$ Dept of \\ Infectious, Gastrointestinal and Hepatology Diseases, Faculty of Medicine, Suez University, Egypt
}

\begin{abstract}
Background: Egypt is considered one of the highly endemic countries with Hepatitis C Virus (HCV) infection. Since we are moving into the HCV-free era, it is necessary to acknowledge the most common methods of HCV transmission. Intrafamilial transmission is one important method that hugely contributed to that endemicity. Aim: Our aim is to identify the prevalence of intrafamilial transmission of HCV among household contacts of chronic HCV patients, risk factors, and methods of transmission. Subjects and Methods: In this study, we recruited 807 Household members of 228 chronic HCV patients. Eligible participants were subjected to history taking, clinical examination, and blood testing for HCV antibodies and PCR. Results: We found that HCV infection was more prevalent among older age groups; married; who live in rural residence; and having high crowding index. Among relatives with HCV, parents were the most affected, followed by siblings, then husbands or wives. The longer the duration of contact, the higher the risk of infection. The incidence of HCV infection was significantly higher among patients who did the following activities: Sharing shaving machine and sugar measurement device with HCVinfected family members, sharing towels with family members, and Handshaking/kissing HCVinfected relatives. Conclusions: Intrafamilial transmission of HCV is an undeniable risk factor, which amplified the burden of HCV. Recognition of remarkable modes of intrafamilial transmission would facilitate suppression of infectivity, as a result achieving the ambition of an HCV-free Egypt.
\end{abstract}

Keywords: HCV, viral infections, household transmission

\section{Introduction}

Hepatitis C Virus (HCV) infection is a concerning global health issue; approximately 80 million people are chronically infected worldwide, with 3 to 4 million recent infections and 672,000 deaths per year due to HCV-associated complications. HCV contributes to about $27 \%$ of cirrhotic cases and $25 \%$ of hepatocellular carcinoma all over the world ${ }^{(1,2)}$. Egypt is one of the highest countries in HCV prevalence rate in the world. In 2015, the prevalence of HCV antibodies and HCV RNA among those who are between 15 and 59 years was found to be $10 \%$ and $7 \%$ respectively $(3)$. 
The common risk factors for HCV infection include a history of anti-schistosomal injections before 1986, senility, male gender, and rural regions habitation. Other risk factors comprise recurrent blood transfusion, frequent hospitalization, and occupational transmission among healthcare workers( ${ }^{(4)}$. Noticeably, the intrafamilial transmission is an important but overlooked risk factor. HCV intrafamilial transmission is defined as HCV transmission between patients infected with $\mathrm{HCV}$ and their household members, including siblings, parents, offspring, and sexual partners living in the same household(5). The prevalence of HCV transmission between family members remains poorly characterized. This is attributed to the limited availability of samples from the early stage of infection, as well as methodological constraints( ${ }^{(6)}$ Thus, in this study, we estimated the prevalence of intrafamilial transmission of HCV among household contacts of chronic HCV Egyptian patients to show whether intrafamilial HCV transmission makes any significant contribution to the global burden of HCV infection.

\section{Subjects and Method}

This is a cross-section study, which was conducted at the Communicable Diseases Research and Training Center (CDRTC) in Suez City. The study included 807 Household members of 228 chronic HCV patients who were followed up by the CDRTC. Inclusion criteria comprised all household members of HCV patients who are between 1 and 60 years old. After obtaining an informed consent, data collection was performed through a questionnaire survey to detect the risk factors for intrafamilial transmission of HCV infection and methods of transmission. In addition, we collected venous blood samples for testing HCV antibodies and HCV RNA to estimate the prevalence of $\mathrm{HCV}$ antibodies among household members of $\mathrm{HCV}$ infected patients. This study was approved by the committee of ethics at the faculty of medicine and Suez Canal University. Respondents positive for hepatitis $C$ were referred to additional screening and counseling at a special Liver Treatment Center.

\section{Results}

The study included 807 subjects whose ages ranged between 1 and 60 years old. The frequency of positive HCV antibodies was higher among patients in the age categories 30-45 and 45-60. Other factors related to HCV infection include being married; live in rural residence; and having high crowding index (Table 1 and 4). Among relatives with $\mathrm{HCV}$, parents were the most affected, followed by siblings, then husbands or wives. The longer the duration of contact, the higher the risk of infection (Tables 2 and 5). The incidence of HCV infection was significantly higher among patients who underwent the following activities: previous operations, endoscopies, syringe reuse, teeth extraction, circumcision, dialysis, and blood transfusion, in addition to sharing shaving machine and sugar measurement device with HCV-infected family members, sharing towels with family members and Handshaking/kissing HCV-infected relatives (Tables 3 and 6).

\section{Discussion}

Previously, drug use was considered the main source of HCV infection for which many measures have been successfully implemented to reduce the global burden ${ }^{(7)}$. Recently, several studies reported that HCV infection might cluster in families or households. Whether horizontal transmission makes any significant contribution to the global burden of HCV infection is still controversial(5). Thus, the present study aimed at estimating of the preva- 
lence of HCV infection among household members of chronic HCV patients and detecting risk factors for intrafamilial transmission of HCV infection. Using HCV-Ab testing, there were 112 patients (13.9\%) diagnosed with HCV while using PCR, HCV diagnosis was established in 100 patients (12.4\%).

Table 1: Participants' demographics

\begin{tabular}{|c|c|c|c|c|}
\hline & $\begin{array}{l}\text { Total } \\
\mathrm{N}=807\end{array}$ & $\begin{array}{c}\mathrm{HCV}-\mathrm{Ab}+\mathrm{ve} \\
\mathrm{n}=112\end{array}$ & $\begin{array}{c}\text { HCV-Ab -ve } \\
n=695\end{array}$ & $P$ value \\
\hline \multicolumn{5}{|l|}{ Age (years) } \\
\hline $1-18$ & $142(19.1)$ & $1(0.9)$ & $141(22)$ & \multirow{4}{*}{$<0.001 *$} \\
\hline $18-30$ & $230(31.0)$ & $15(13.4)$ & $215(33.8)$ & \\
\hline $30-45$ & $254(31.5)$ & $41(36.6)$ & $207(29.8)$ & \\
\hline $45-60$ & $181(22.4)$ & $55(49.1)$ & $126(18.1)$ & \\
\hline \multicolumn{5}{|l|}{ Sex } \\
\hline Male & $404(50.1)$ & $58(51.8)$ & $346(49.8)$ & \multirow[t]{2}{*}{0.69} \\
\hline Female & $403(49.9)$ & $54(48.2)$ & $349(50.2)$ & \\
\hline \multicolumn{5}{|l|}{ Socioeconomic status } \\
\hline Low & $345(42.8)$ & $52(46.4)$ & $293(36.3)$ & \multirow{3}{*}{0.53} \\
\hline Medium & $364(45.1)$ & $45(40.2)$ & $319(33.8)$ & \\
\hline High & $98(12.1)$ & $15(13.4)$ & $83(23.9)$ & \\
\hline \multicolumn{5}{|l|}{ Marital status } \\
\hline Single & $258(32.0)$ & $11(9.8)$ & $247(35.5)$ & \multirow{3}{*}{$<0.001^{*}$} \\
\hline Divorced/widowed & $106(13.1)$ & $22(19.6)$ & $84(12.1)$ & \\
\hline Married & $443(54.9)$ & $79(70.5)$ & $364(52.4)$ & \\
\hline \multicolumn{5}{|l|}{ Residence } \\
\hline Urban & $463(57.4)$ & $30(26.8)$ & $433(62.3)$ & \multirow[t]{2}{*}{$<0.001 *$} \\
\hline Rural & $344(42.6)$ & $92(82.1)$ & $262(37.7)$ & \\
\hline
\end{tabular}

Whether horizontal transmission makes any significant contribution to the global burden of HCV infection is still controversial(5). Thus, we aimed at estimating of the prevalence of HCV infection among household members of chronic HCV patients and detecting risk factors for intrafamilial transmission of HCV infection. Using HCV-Ab testing, 112 patients (13.9\%) were diagnosed with HCV while using PCR, HCV was established in 100 patients (12.4\%). The remarkable personal risk factors of HCV were old age; marriage; rural residence and high crowding index. These findings agree with Bettaieb et al who proved that increasing age was associated with an increasing prevalence of HCV infection ${ }^{(8)}$. Another Egyptian study had identified the role of $\mathrm{HCV}$ transmission among household contacts to index cases; they found that HCV-positive contacts were more likely older; married and had higher crowding index than HCV-negative contacts $(9)$. In addition, Ndong-Atome et al found that age over 50 years was the only independent predictor of positivity for HCV antibody among family members ${ }^{(10)}$. On the other hand, an Egyptian study by Mohamed et al. found that the highest incidence rate was among children less than 10 yrs old who reside in households with an anti-HCV-positive parent ${ }^{(11)}$. 
Table 2: Details of HCV Ab positive contacts

\begin{tabular}{|c|c|c|c|c|}
\hline & $\begin{array}{c}\text { Total } \\
\mathrm{N}=807\end{array}$ & $\begin{array}{c}\text { HCV-Ab +ve } \\
n=112\end{array}$ & $\begin{array}{c}\text { HCV-Ab -ve } \\
n=695\end{array}$ & $P$ value \\
\hline \multicolumn{5}{|l|}{ Relatives with $\mathrm{HCV}$} \\
\hline Parents & $480(59.4)$ & $62(55.4)$ & $418(46.8)$ & \multirow{4}{*}{$<0.001^{*}$} \\
\hline Siblings & $219(27.1)$ & $24(21.4)$ & $195(2.3)$ & \\
\hline Husband/wife & $55(6.9)$ & $20(17.9)$ & $35(5.0)$ & \\
\hline Other cohabitants & $53(6.6)$ & $6(5.4)$ & $47(45.9)$ & \\
\hline \multicolumn{5}{|l|}{ Duration of contact (Years) } \\
\hline$<1$ & $103(12.8)$ & $15(13.4)$ & $98(14.1)$ & \multirow{4}{*}{$0.018 *$} \\
\hline $1-3$ & $135(16.7)$ & $15(13.4)$ & $120(17 \cdot 3)$ & \\
\hline $3-5$ & $329(40.8)$ & $34(30.4)$ & $295(42.4)$ & \\
\hline$>5$ & $240(29.7)$ & $48(42.9)$ & $192(27.6)$ & \\
\hline \multicolumn{5}{|l|}{ Crowding index } \\
\hline$\leq 1: 1$ & $109(13.5)$ & $17(15.2)$ & $92(13.2)$ & \multirow{3}{*}{$0.006^{*}$} \\
\hline 2:1 & $467(57.9)$ & $77(68.8)$ & $390(56.1)$ & \\
\hline $3: 1$ & $231(28.6)$ & 18 16.1) & $213(30.6)$ & \\
\hline
\end{tabular}

Advancing age is mostly associated with more chronic illnesses and frequent hospital admissions, thus more vulnerability to blood withdrawing processes, injections, and even transfusion. All these factors raise the susceptibility of getting infected with HCV. The reason why HCV infection is prevalent among rural areas because there is a high crowding index, low socioeconomic status exists, and lack of knowledge. This agrees with previous studies locally and internationally $(8,12,13)$. We found that the incidence of intrafamilial transmission was the highest from parents, followed by siblings, then husbands and wives. Longer duration of contact with positive cases was also associated with a higher incidence of HCV infection. In a similar study, Lankarani et al found that in 18 out of 34 families, the HCV antibody was detected in new members (52.9\%). Among 11 families of them, HCV transmission was also confirmed by PCR $(32 \%)^{(14)}$. In an Egyptian study by Omar et al. included 90 families of patients with confirmed chronic HCV and 38 families of
non-HCV-infected persons, the incidence of HCV infection was higher among those in contact with cases who are positive to HCV. Thirty-seven families (41\%) had at least one HCV infected contact ${ }^{(12)}$. Albeit, in an Iranian study that aimed to determine intrafamilial seropositivity of $\mathrm{HCV}$ noted that only $1.3 \%$ of family members were HCV Ab positive(15). Similarly, a study by Plancoulaine et al found remarkable intrafamilial transmission trends among patients with HCV and their contacts. The positive transmission was confirmed between father-offspring, mother-offspring, and sibling-sibling, while a weaker dependence between spouses was observed ${ }^{(19)}$. In contrast to our findings, Omar et al found that the majority of transmissions were between husbands and wives, followed by siblings (12) This was augmented by de Waure et al findings who concluded that the highest pooled prevalence was found among sexual partners of index cases $^{(16)}$. This agrees with Minola et al who noted that HCV antibodies were detected in $2.1 \%$ of the members 
of their original families, and in $13.8 \%$ among sexual partners (17) While Del Corno and Civardi the authors found no evidence of a higher risk of HCV infection in spouses due to anti-HCV positivity in their partners(18). Many people think that sexual transmission is a major risk factor for $\mathrm{HCV}$ intrafamilial transmission.

Table 3: Modes of HCV transmission

\begin{tabular}{|c|c|c|c|c|}
\hline & $\begin{array}{c}\text { Total } \\
\mathrm{N}=807\end{array}$ & $\begin{array}{c}\text { HCV-Ab +ve } \\
n=112\end{array}$ & $\begin{array}{c}\text { HCV-Ab -ve } \\
n=695\end{array}$ & $P$ value \\
\hline - Previous operations & $504(62.5)$ & $89(79.5)$ & $415(59.7)$ & $<0.001 *$ \\
\hline - Previous endoscopy/catheters & $77(9.5)$ & $28(25.0)$ & $49(7.1)$ & $<0.001 *$ \\
\hline - Tattooing & $78(9.7)$ & $12(10.7)$ & $66(9.5)$ & 0.69 \\
\hline - Nose/ear piercing & $400(49.6)$ & $57(50.9)$ & $343(49.4)$ & 0.76 \\
\hline - Syringe reuse & $40(5.0)$ & $18(16.1)$ & $22(3.2)$ & $<0.001 *$ \\
\hline - Acupuncture & $30(3.7)$ & $1(0.9)$ & $29(4.2)$ & 0.09 \\
\hline - Shaving beard by barber & $273(33.8)$ & $42(37.5)$ & $231(33.2)$ & 0.67 \\
\hline - Cleaning/braiding nails by barber & $130(16.1)$ & $15(13.4)$ & $115(16.5)$ & 0.4 \\
\hline - Teeth extraction & $613(76.0)$ & $104(92.9)$ & $509(73.2)$ & $<0.001 *$ \\
\hline - Circumcision & $703(87.1)$ & $105(93.8)$ & $598(86.0)$ & $0.024^{*}$ \\
\hline - Dialysis & $9(1.1)$ & $4(3.6)$ & $5(0.7)$ & $0.008^{*}$ \\
\hline - Blood transfusion & $58(7.2)$ & $19(17.0)$ & $39(5.69)$ & $<0.001 *$ \\
\hline $\begin{array}{l}\text { - Injections for treatment for } \\
\text { bilharziasis }\end{array}$ & $79(9.8)$ & $20(17.9)$ & $59(8.5)$ & 0.09 \\
\hline - Insulin injections & $47(5.8)$ & $14(12.5)$ & $33(4.7)$ & 0.55 \\
\hline $\begin{array}{l}\text { - Sharing nail scissors with HCV- } \\
\text { infected family members }\end{array}$ & $514(63.7)$ & $70(62.5)$ & $444(63.9)$ & 0.78 \\
\hline $\begin{array}{l}\text { - Sharing shaving machine with } \\
\text { HCV-infected family members }\end{array}$ & $33(4.1)$ & $10(8.9)$ & $23(3.3)$ & $<0.001^{*}$ \\
\hline $\begin{array}{l}\text { - Sharing toothbrush with HCV- } \\
\text { infected family members }\end{array}$ & $11(1.4)$ & $3(2.7)$ & $8(1.2)$ & 0.15 \\
\hline $\begin{array}{l}\text { - Sharing sugar measurement } \\
\text { device with HCV-infected family } \\
\text { members }\end{array}$ & $23(2.9)$ & $13(11.6)$ & $10(1.4)$ & $0.004^{*}$ \\
\hline $\begin{array}{l}\text { - Shesha sharing with HCV-infected } \\
\text { relatives }\end{array}$ & $43(5.3)$ & $3(2.7)$ & $40(5.8)$ & 0.18 \\
\hline $\begin{array}{l}\text { - Sharing towels with HCV-infected } \\
\text { family members }\end{array}$ & $629(77.9)$ & $84(75.0)$ & $545(78.4)$ & 0.42 \\
\hline $\begin{array}{l}\text { - Sharing clothes with HCV-infected } \\
\text { family members }\end{array}$ & $238(29.5)$ & $33(29.5)$ & $205(29.5)$ & 0.99 \\
\hline $\begin{array}{l}\text { - Using the same WC used by HCV- } \\
\text { infected family members }\end{array}$ & $748(92.7)$ & $108(96.4)$ & $640(92.1)$ & 0.14 \\
\hline $\begin{array}{l}\text { - Sharing food utensils with HCV- } \\
\text { infected family members }\end{array}$ & $775(96.0)$ & $109(97.3)$ & $666(95.8)$ & 0.45 \\
\hline $\begin{array}{l}\text { - Handshaking/kissing } \mathrm{HCV} \text {-infected } \\
\text { relatives }\end{array}$ & $679(84.1)$ & $106(94.6)$ & $573(82.4)$ & $0.001^{*}$ \\
\hline
\end{tabular}

*P value $<0.005=$ significant 
Table 4: Participants' demographics according to $P C R$ results

\begin{tabular}{|l|c|c|c|c|}
\hline & $\begin{array}{c}\text { Total } \\
\mathrm{N}=807(\%)\end{array}$ & $\begin{array}{c}\mathrm{PCR}+\mathrm{ve} \\
\mathrm{n}=100(\%)\end{array}$ & $\begin{array}{c}\mathrm{PCR}-\mathrm{ve} \\
\mathrm{n}=707(\%)\end{array}$ & $\mathrm{P}$ value \\
\hline Age (years) & $32(4.0)$ & $1(1.0)$ & $121(17.1)$ & \\
$1-12$ & $340(46.1)$ & $14(14)$ & $326(46.1)$ & $<0.001^{*}$ \\
$18-30$ & $254(31.5)$ & $34(34.0)$ & $220(31.1)$ & \\
$30-45$ & $181(22.4)$ & $55(49.1)$ & $132(18.1)$ & \\
$45-60$ & & & & \\
\hline Sex & $404(50.1)$ & $51(51.0)$ & $353(49.9)$ & 0.84 \\
Male & $403(49.9)$ & $49(49.0)$ & $354(50.1)$ & \\
Female & & & & \\
\hline Socioeconomic status & $345(42.8)$ & $43(43.0)$ & $302(42.7)$ & \multirow{2}{*}{0.17} \\
Low & $364(45.1)$ & $26(26.0)$ & $238(33.7)$ & \\
Medium & $98(12.1)$ & $31(31.0)$ & $167(23.6)$ & \\
High & & & & \\
\hline Marital status & $258(32)$ & $10(10.0)$ & $248(35.1)$ & \multirow{2}{*}{ Single } \\
$\begin{array}{l}\text { Divorced/widowed } \\
\text { Married }\end{array}$ & $106(13.1)$ & $20(20.0)$ & $86(12.2)$ & \\
\hline Residence & $443(54.9)$ & $70(70.0)$ & $373(52.8)$ & \\
Urban & & & & \\
Rural & $463(57.4)$ & $26(26.0)$ & $437(61.8)$ & $<0.001^{*}$ \\
\hline
\end{tabular}

*P value $<0.005=$ significant

However, sexual exposure is considered a low-risk activity that barely transmits HCV infection among HCV positive sexual partners. It is believed that other high to moderate risk activities are to be blamed for this assumption. For example, sharing razors and toothbrushes between couples who have a sexual partnership is one of these activities ${ }^{(13)}$. This discrepancy among various studies in the incidence of transmission between different family members is attributed to the discrepancy in the duration of contact with those positive contacts regardless of kinship. Evidently, the longer the duration of contact with an HCV-infected relative, the higher the risk of transmission ${ }^{(20,21)}$. In our study, the incidence of HCV infection was significantly higher among patients who performed the following activities: sharing shaving machines and sugar measurement device with HCV-infected family members, sharing towels with family members, and Handshaking/kissing HCV-infected relatives. In agreement with our data, the study of Akhtar et al found that the HCVseropositive household contacts were more likely than HCV seronegative household contacts to have been bitten by the carrier or have shared a toothbrush with the carrier(22). Our findings are also in harmony with the conclusions of Cavalheiro_et al who reported that risk factors for intrafamilial HCV acquisition included the shared use of personal hygiene items included toothbrushes, razor blades, nail clippers, and manicure pliers ${ }^{(6)}$. Moreover, Sherief et al found that female caregivers, particularly mothers, contact with index cases blood. This either happens directly 
without using personal protective equipment or indirectly through common use of sharps (razors, scissors) and nail clippers, in addition to giving care to HCV infected cases $^{(23)}$. Apart from sharing towels with relatives who are positive to $\mathrm{HCV}$ and handshaking/kissing with them, there is an agreement over the activities that massively contribute to infection transmission. This agreement is proved among all previous studies. We also included the incidence of the already established basic methods of transmission to recognize the essential sources of infection.

Table 5: Details of HCV PCR positive contacts

\begin{tabular}{|l|ccc|c|}
\hline & $\begin{array}{c}\text { Total } \\
\mathrm{N}=807(\%)\end{array}$ & $\begin{array}{c}\mathrm{PCR}+\mathrm{ve} \\
\mathrm{n}=100(\%)\end{array}$ & $\begin{array}{c}\mathrm{PCR}-\mathrm{ve} \\
\mathrm{n}=707(\%)\end{array}$ & P value \\
\hline Relatives with HCV & & & & \\
$\quad$ Parents & $480(59.4)$ & $66(46)$ & $414(58.6)$ & \\
Sibling & $219(27.1)$ & $13(13.0)$ & $206(29.2)$ & $<0.001^{*}$ \\
Husband/wife & $55(6.9)$ & $20(20.0)$ & $35(4.9)$ & \\
Other cohabitants & $53(6.6)$ & $1(1)$ & $52(7.4)$ & \\
\hline Duration of contact_(Years) & & & & \\
$<1$ & $103(12.8)$ & $14(14.0)$ & $98(13.9)$ & \\
$1-3$ & $135(16.7)$ & $12(12.0)$ & $120(17.0)$ & $0.018^{*}$ \\
$3-5$ & $329(40.8)$ & $30(30.3)$ & $295(41.7)$ & \\
$>5$ & $240(29.7)$ & $44(44)$ & $192(27.2)$ & \\
\hline Crowding index & & & & \\
$\leq 1: 1$ & $109(13.5)$ & $14(14.0)$ & $95(13.4)$ & \multirow{2}{*}{$0.04^{*}$} \\
$2: 1$ & $467(57.9)$ & $68(68.0)$ & $399(56.4)$ & \\
$3: 1$ & $231(28.6)$ & $18(18.0)$ & $213(30.1)$ & \\
\hline
\end{tabular}

*P value $<0.005$

\section{Conclusion}

We hereby reporting the paramount role of intrafamilial transmission in the spread of HCV infection, in addition to highlighting the most common transmission methods. To the best of our knowledge, our study was one of the fewest Egyptian studies, which included a detailed description of the incidence of household contact transmission, and specified listing of common and even uncommon modes of $\mathrm{HCV}$ infection transmission. The implication of these data is priceless for the achievement of total eradication of this global burden.

\section{References}

1. Gower E, Estes C, Blach S, Razavi-Shearer $\mathrm{K}$, Razavi H. Global epidemiology, and genotype distribution of the hepatitis $C$ virus infection. J hepatol.. 2014;61(1), S45S57.

2. World Health Organization. Global health sector strategy on viral hepatitis 20162021. Glob Hepat Program Dep HIV/AIDS. June 2016

3. El-Zanaty F, and Way A. Egypt Demographic and Health Survey 2014. Cairo, Egypt: Ministry of Health, El-Zanaty and Associates, and Macro International, 2015

4. Shepard CW, Finelli L, Alter MJ . Lancet Infec Dis. 2005;5(9), 558-67 
5. Indolfi G, Nesi A, Resti M. Intrafamilial transmission of hepatitis $C$ virus. J Med Virol. 2013; 85(4), 608-614

6. Cavalheiro Nde P, De La Rosa A, Elagin S, Tengan FM, Arau'jo ES, Barone AA. Hepatitis C: Sexual or intrafamilial transmission? Epidemiological and phylogenetic analysis of hepatitis $C$ virus in 24 infected couples. Rev Soc Bras Med Trop. 2009; 42:239-244.

7. Zhou B, Cai GFF, Lv HKK, Xu SFF, Wang ZTT, Jiang ZGG, Hu CGG, Chen YDD. Factors Correlating to the Development of Hepatitis C Virus Infection among Drug Users-Findings from a Systematic Review and Meta-Analysis. Int J Environ Res Public Health. 2019;16(13), 2345.

8. Bettaieb J, Chouikha A, Khedhiri, Marwa Bettaieb, J. et al.,. Hepatitis C virus epidemiology in Central - West Tunisia : a population - based cross - sectional study. Arch Virol. 2019; 164(9): 2243-2253.

9. Bayomy Helal HE, Yuonis A, Shaker RHM, Elawady MA. Prevalence of HCV Infection in Household Contacts of Chronic Liver Diseases Cases in Egypt. Int J Environ Res Public Health., 2018; 2153537.

10. Ndong-Atome GR, Njouom R, Padilla C, Bisvigou U, Makuwa M, Kazanji M. Absence of intrafamilial transmission of hepatitis $C$ virus and low risk for sexual transmission in rural central Africa indicate a cohort effect. J Clin Virol 2009;45(4), 349-353.

11. Mohamed MK, Abdel-Hamid M, Mikhail NN, Abdel-Aziz F, Medhat A, Magder LS, Fix AD, Strickland GT. Intrafamilial transmission of hepatitis C in Egypt. Eur J Epidemiol, 2005;21:293-297.

12. Omar MZ, Metwally MA, El-Feky HM, Ahmed IA, Ismail MA, Idris A. Role of intrafamilial transmission in high prevalence of hepatitis C virus in Egypt. Hepatic medicine: Hepat Med. 2017; 9, 27-33.

13. Badr R, Korah T, Tawfeek A, et al. A study on how patients catch hepatitis $C$ virus. Menoufia Med J 2016; 29:215-221.

14. Lankarani KB, Ardebili M, Sepehrimanesh M, Nejabat M, Rad MA, Hosseini SY. Evaluation of hepatitis $C$ virus intrafamilial transmission among families with one in- dex case, a pilot study from Fars province, Iran. Gastroenterol Hepatol Bed Bench. 2016;9(4), 250.

15. Ranjbar M, Golzardi Z, Sedigh L, Nekoozadeh S. Intrafamilial seropositivity of hepatitis in patients with hepatitis B and $C$ virus in hepatitis clinic in Hamadan, Iran. Ann Hepatol.. 2012; 11(1), 32-36.

16. Plancoulaine S, Mohamed MK, Arafa N, Bakr I, Rekacewicz C, Tre'goue"t DA, Obach D, El Daly M, Thiers V, Fe'ray C, Abdel-Hamid M, Abel L, Fontanet A. Dissection of familial correlations in hepatitis $\mathrm{C}$ virus (HCV) seroprevalence suggests intrafamilial viral transmission and genetic predisposition to infection. Gut. 2008; 57:1268-1274.

17. de Waure C, Cefalo C, Chiaradia G, et al Intrafamilial transmission of hepatitis $C$ virus in Italy: a systematic review. J Epidemiol Community Health.. 2010; 64(10), 843-848.

18. Minola E, Baldo V, Baldovin T, Trivello R, Floreani A. Intrafamilial transmission of hepatitis $C$ virus infection. Eur J Epidemiol., 2006; 21(4), 293-297.

19. Del Corno G, Civardi E. Intrafamilial transmission of hepatitis $B$ and $C$ viruses in an Italian local health district. Ann Ig: medicina preventiva e di comunita. 2006; 18(4), 287-295

20. Jamil Z, Waheed $Y$, Yousuf H. Familial clustering of hepatitis $C$ virus in a Pakistani population. J Med Virol.. 2020.

21. Hajiani E, Masjedizadeh R, Hashemi J, Azmi M, Rajabi T.. Hepatitis C virus transmission and its risk factors within families of patients infected with hepatitis $C$ virus in southern Iran: Khuzestan. WJG. 2006;12(43):7025-7028.

22. Akhtar S, Moatter T, Azam SI, Rahbar $\mathrm{MH}$, Adil S. Prevalence and risk factors for intrafamilial transmission of hepatitis $C$ virus in Karachi, Pakistan. J Viral Hepat. 2002; 9(4), 309-314.

23. Sherief LM, Beshir MR, Salem GM, et al. Intrafamilial Transmission of Hepatitis C Virus Among Families of Infected Pediatric Oncology Patients. Pediatr Infect Dis J, 2019;38(7), 692-697. 